
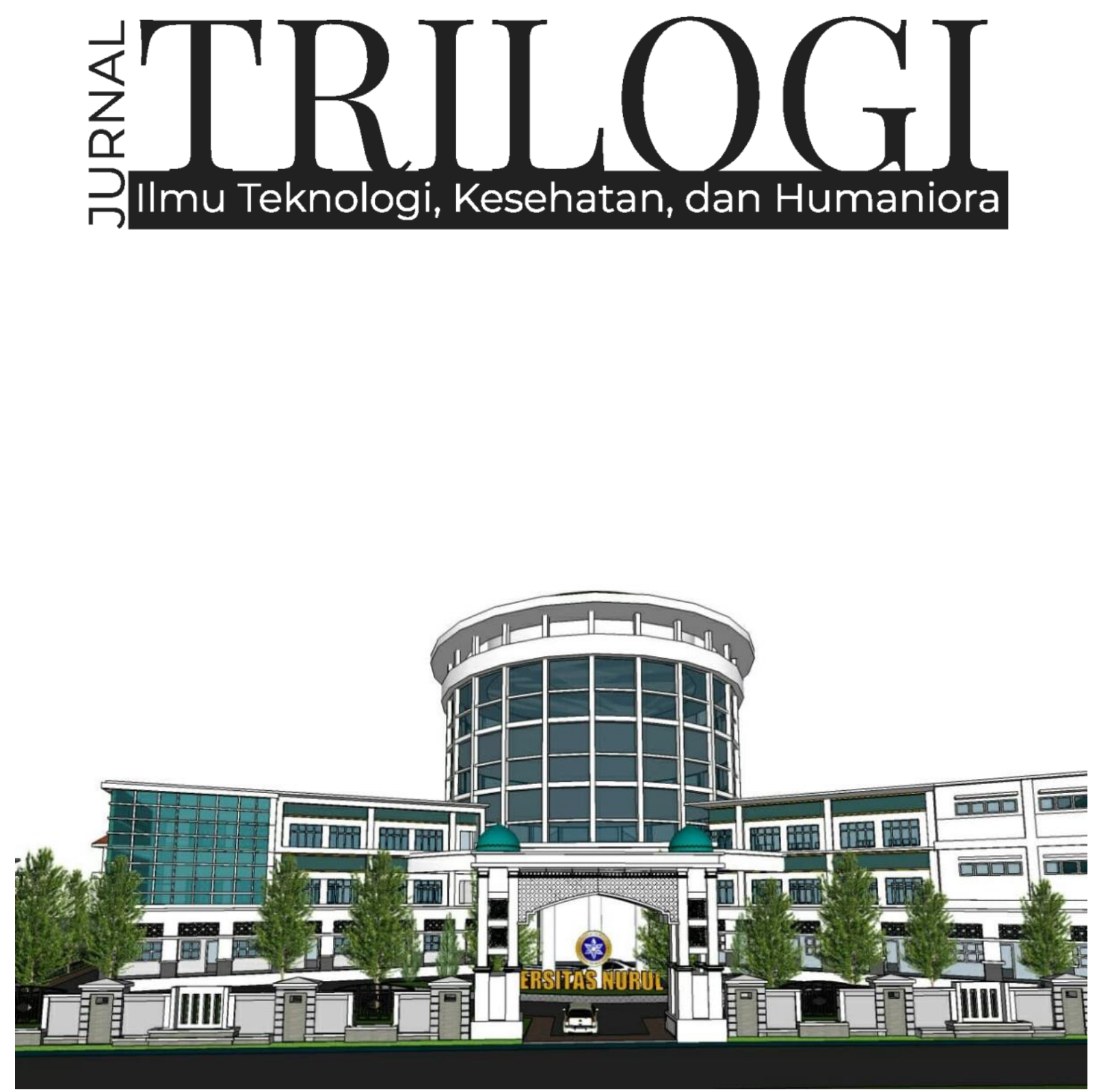

PENGEMBANGAN PENDIDIKAN DAN EKONOMI PESANTREN DI MASA PANDEMI COVID-19 


\section{犃BUOGI}

Vol. 2, No. 2, 2021

Editor in Chief

Achmad Fawaid, (SCOPUS ID: 57214837323)

\section{Managing Editors}

Hasan Baharun, (ID SCOPUS : 57200983602)

Sugiono Sugiono, (SCOPUS ID : 57199578160)

Ismail Marzuki, (SCOPUS ID: 57201500245

Subhan Rachman, (SCOPUS ID: 57192937912)

Nurul Huda, (SINTA ID: 6119615)

Syamsuri, (SINTA ID: 6116825)

Ridhatullah Assya'bani, (SINTA ID: 6200862)

\section{Peer Reviewers}

Miftahul Huda, (SINTA ID: 6171566), University of Antwerp, Belgium

Achmad Naufal Irsyadi, (SINTA ID: 6704870), Universitas Nurul Jadid, Indonesia

Gulpi Qorik Oktagalu P., (SINTA ID: 5982074) Universitas Nurul Jadid Probolinggo, Indonesia Hozairi, (SINTA ID: 166198), Universitas Islam Madura, Indonesia

Nur Hamid, (SINTA ID : 6744813), Univeristas Nurul Jadid Probolinggo, Indonesia Zainal Munir, (SINTA ID: 6672512), Universitas Nurul Jadid Probolinggo, Indonesia Sri Astutik Andayani, (SINTA ID: 6172559), Universitas Nurul Jadid Probolinggo, Indonesia Sukamto Sukamto, (SINTA ID: 5979034), Universitas Widya Gama Malang, Indonesia Deny Utomo, (SINTA ID: 6016108), Universitas Yudharta Pasuruan, Indonesia Fariz Alnizar, (SCOPUS ID: 6659824), UNUSIA Jakarta, Indonesia

Fuad Rahman, (SCOPUS ID: 57201474778), UIN Sulthan Thaha Saifuddin Jambi, Indonesia Saifuddin Zuhri Qudsy, (SCOPUS ID: 57213595165), UIN Sunan Kalijaga Yogyakarta, Indonesia Akhmad Anwar Dani, (SINTA ID: 14305), IAIN Surakarta, Indonesia

Maufur Maufur, (SINTA ID: 5989329), IAIN Kediri, Indonesia

Siti Mahmudah Noorhayati, (SINTA ID: 6726997), IAIN La Roiba Bogor, Indonesia Busro Busro, (SCOPUS ID: 57205022652), UIN Sunan Gunung Djati Bandung, Indonesia Akmal Mundiri, (SCOPUS ID: 57205059378), UNUJA Probolinggo, Indonesia

\section{Section Editor}

Ahmad Zubaidi, Universitas Nurul Jadid, Probolinggo, Indonesia 
TRILOGI: Jurnal IImu Teknologi, Kesehatan, dan Humaniora is a peer-reviewed journal, open-access journal which publishes original articles on various issues within technology, health, and social humanities, which include but are not limited to newrenewable energy, food-agriculture, health-pharmacy, transportation, informationcommunication technology, advanced-materials, maritime-infrastructre, social-artseducation, and religious studies based on academic and scientific research.

TRILOGI: Jurnal IImu Teknologi, Kesehatan, dan Humaniora seeks to publish a balanced mix of theoretical or empirical articles, case studies, review papers, comparative studies, exploratory papers, and book reviews. All accepted manuscripts will be possibly published both online and in printed forms.

Editorial Office:

TRILOGI: Jurnal IImu Teknologi, Kesehatan, dan Humaniora Lembaga Penerbitan, Penelitian, dan Pengabdian kepada Masyarakat (LP3M) Universitas Nurul Jadid, Paiton, Probolinggo, Jawa Timur, Indonesia 67291.

Phone: 088830 77077, Hp: 082318007953

Email: jurnal.trilogi@gmail.com

Website: https://ejournal.unuja.ac.id/index.php/trilogi/index 


\section{Tables of Content}

71-76

Pengaruh Metode Pembelajaran Daring dengan Aplikasi Google Classroom terhadap Hasil Belajar Siswa Madrasah Ibtidaiyah Nurul Mun'im Paiton Probolinggo

Feriska Listrianti, Lailatul Munawwaroh, Sayyidatul Arifa, Siti Aisyah

77-84

Inklusivitas dan Responsivitas Pesantren dalam Penanganan Pandemi Covid 19: Telaah Hidden Curriculum Pembelajaran di Pondok Pesantren Nurul Jadid

Zakiyah BZ, Uswatun Hasnah, Nafistur Rahmah

84-94

Integrasi Kurikulum Madrasah Diniyah dengan Lembaga Formal dalam Meningkatkan Mutu Lulusan di Sekolah Menengah Pertama (SMP) Nurul Jadid Paiton Probolinggo

Abdurrahman, Ika Fitri Anwar, Sofiya Mauliza, Nadya Afkarina

95-104

Some Issues on Time Deposit Financing: An Islamic Perspective on Mudharabah Agreement at Baitul Maal wa Tamwil (BMT) NU in Randuagung Lumajang

Saifuddin, Abdul Hafid, Hengki Wahyu Pratama

$105-110$

Analisis Pengembangan Potensi Ekonomi Keluarga melalui Unit Usaha Kapuk

Fahrudin, Iis Sa'diyah, Rizaldi Chandra Gunawan

111-117

Penguatan Ekonomi Pesantren melalui Pengembangan Ekonomi Masyarakat Pesisir: Pelajaran dari Pondok Pesantren Nurul Jadid Paiton Probolinggo

Achmad Febrianto, Muhammad Habibullah, Aksal Ilhamsyah

118-125

Prevensi Perilaku Konsumtif Persepektif Abraham Maslow dan Tri Logi Santri

Muhammad Syaiful Suib, Habibatur Rizkiyah, Fitria Nur Ain 
$126-136$

Manajemen Pengembangan Kurikulum Berorientasi pada Pembentukan Karakter

Moh Rifa'i, Fatimah Al Zahra, Abdurrahman Abdurrahman, Mukhlisin Saad

137-147

Home Industry, Kaderisasi, dan Santripreneur

Muh Hamzah, Aprilinda Dwi Kurniawati, Husnul Khotimah

148-157

Rancangan Pengelolaan Nirsampah Mandiri Skala Lembaga Pendidikan

Tirmidi, Eril Sinta Nuriyah, Rofi'ah

158-166

Parents' Knowledge and Commitment To Stimulate Child Development

Lailatul Fitriyah, Nurul Islamiyah, Auliya' Fatahillah

167-172

Implementasi Pembelajaran Akhlak Berbasis Multikultural pada Masa Pandemi di Madrasah Tsanawiyah Nurul Jadid Paiton Probolinggo

Abdullah, Yusrolana, Nur Laily

$173-183$

Implementasi Evaluasi Pembelajaran Daring (Online) melalui Home Visit

Moch Tohet, Moh. Bagus Abdillah, Adam Hakim Al Rizki

184-192

Efektivitas Pembelajaran Luring pada Mata Pelajaran Matematika selama Pandemi Covid-19

Zaenol Fajri, Sukron Junaidi, Hamdani Alfarisi 
P-ISSN: 2774-4574; E-ISSN: 2774-4582

TRILOGI, 2(2), Mei-Agustus 2021 (148-157) @2021 Lembaga Penerbitan, Penelitian, dan Pengabdian kepada Masyarakat (LP3M) Universitas Nurul Jadid Paiton Probolinggo

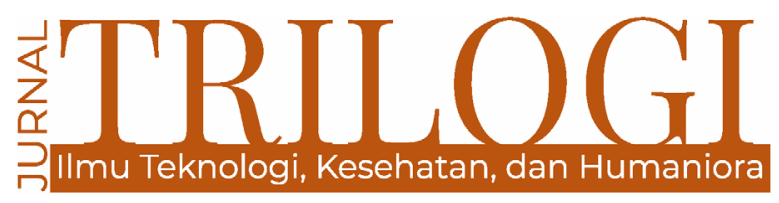

\title{
RANCANGAN PENGELOLAAN NIRSAMPAH MANDIRI SKALA LEMBAGA PENDIDIKAN
}

\section{Tirmidi}

Universitas Nurul Jadid, Probolinggo

tirmidi1973@gmail.com

\section{Eril Sinta Nuriyah}

Universitas Nurul Jadid, Probolinggo

erilsintanuriah@gmail.com

\section{Rofi'ah}

Universitas Nurul Jadid, Probolinggo

Rovipiahn43@gmail.com

\begin{abstract}
Madrasah Aliyah Nurul Jadid, sebagai sekolah menengah lainnya di Pesantren Nurul Jadid, mempraktikkan paradigma lama pengelolaan limbah padat dalam semua fase-nya, yaitu: mengumpulkan, mengangkut, membuang atau membuang sampah di tempat pembuangan sampah yang tersedia. TPA, sebenarnya, menghadapi limpahan. Desain yang cocok untuk manajemen limbah nol otonom perlu untuk diatasi. Melalui penelitian dan pengembangan ( $R$ \& D) desain, penelitian ini bertujuan untuk menggambarkan praktik pengelolaan limbah yang ada, dan mengusulkan desain yang sesuai untuk implementasi maagement limbah nol otonom di MA Nurul Jadid. Sebagai hasil penelitian, proposal tersebut mencakup desain yang sesuai mengenai institusi, operasi, partisipasi, peraturan, dan pendanaan.
\end{abstract}

Katakunci: pesantren, zero waste management, rancangan, madrasah, Nurul Jadid

\begin{abstract}
Abstrak
Madrasah Aliyah Nurul Jadid, as another secondary school in the Nurul Jadid Islamic Boarding School, practiced the old paradigm of waste management, i.e. collecting, transporting, throwing out, or disposing of garbage in the available waste disposal site. TPA, actually, is dealing with an abundance. The suitable design for autonomous zero waste management needs to be overcome. Through research and development ( $\& D$ ) design, this study aims to describe the practice of existing waste management, and propose a suitable design for the implementation of zero waste maagement in Ma Nurul Jadid. As a result of the study, the proposal includes the appropriate design of institutions, operations, participation, regulations, and funding.
\end{abstract}

Keywords: Islamic Boarding School, Zero Waste Management, Design, Madrasah, Nurul Jadid 


\section{Pendahuluan}

Timbulan sampah di dunia saat ini adalah sebesar 130 juta ton pertahun dimana jumlah ini diperkirakan akan naik menjadi 220 ton per tahun pada tahun 2025 (Kasam et al., 2019). Pada referensi yang lain dinyatakan bahwa jumlah timbulan sampah di tanah air adalah sekitar 67,8 juta ton pada 2020 dan dipastikan akan terus bertambah seiring pertumbuhan jumlah penduduk serta semakin membaiknya tingkat kesejahteraan masyarakat. Wakil Menteri Lingkungan Hidup dan Kehutanan (LHK) Alue Dohong mengakui permasalahan sampah di Indonesia cenderung semakin kompleks dengan rentang masalah yang semakin besar. Dohong juga menekankan bahwa volume sampah terus mengalami peningkatan jumlah, komposisi, dan ragamnya (Anonim, 2020). Lebih jauh lagi permasalahan mendesak yang perlu segera ditangani adalah bahwa dari keseluruhan jumlah yang ada, masih ada 30\% sampah yang tidak tertangani. Artinya masih ada 30\% sampah yang tidak terangkut, tidak terkelola, dan tidak tertangani di masyarakat (Brotosusilo et al., 2020) but also individual/informal/voluntary actions in order to create a healthy environment. This study conducted to unveil the factors that increase individuals' community participation in solid waste management policy. The data were matched with a literature review on existing waste policies to identify gaps in knowledge, which could provide beneficial policy recommendations for the Jakarta Provincial Government. The ordinary least squares regression and Indonesian family life survey data were used. The respondents' waste handling and participation scores with potentially affected variables were calculated and regressed. Out of 1.791 respondents, the regression revealed that the participation of individuals from Jakarta is influenced by 1 .

Di sisi lain, jumlah sampah plastik global setiap tahunnya juga cenderung mengalami peningkatan. Produksi sampah plastik setiap tahunnya merupakan jumlah terbanyak, yakni sebesar 146 juta ton per tahun yang kemudian disusul dengan sampah di bidang bangunan dan konstruksi yang sebanyak 65 juta ton. Tingginya timbulan sampah plastik disebabkan oleh penggunaan produk plastik yang melebihi batas. Ini disebabkan oleh berkembangnya mindset pada sebagian besar masyarakat Indonesia yang menganggap sampah sebagai bahan yang hanya dapat menimbulkan pencemaran lingkungan dan tidak memiliki nilai guna. Padahal materi yang dianggap sampah dapat menjadi sumber daya yang masih dapat dimanfaatkan dan ditingkatkan lagi nilai gunanya. Sampah organik bisa diolah menjadi kompos dan sampah anorganik bisa dioleh menjadi berbagai macam kerajinan (Zaharani et al., 2020). Bila hal itu dapat dilakukan maka tidak tertutup kemungkinan kita akan menjadi zero waste society (Pujiati, 2019).

Dalam keterkaitan ini, Pesantren Nurul Jadid Paiton Probolinggo yang merupakan pesantren dengan jumlah santri sebanyak 7539 orang, hingga saat ini masih menerapkan pola kumpul, angkut, dan timbun/bakar dalam pengelolaan sampahnya. Oleh karena itu, tidak terhindarkan bahwa Pesantren Nurul Jadid menghadapi masalah penampungan atau penimbunan sampah yang terkumpul setiap harinya karena lahan penampungan sampah yang seluas $3000 \mathrm{~m}^{3}$ sudah tidak mampu menampungnya lagi. Oleh karena itu, bila pola pengelolaan nirsampah mandiri ini dapat dijalankan, Pesantren Nurul Jadid akan mampu mengatasi masalah keterbatasan lahan penampungan sampah; bahkan akan mampu mengambil berkah dari terkelolanya sampah yang ada.

Untuk memulai gerakan ini, perlu diupayakan pola contingent innovation decision dalam teori difusi inovasi, yakni pengambilan keputusan inovasi yang didahului oleh pemberian model terlebih dahulu (Rogers, E.M. et al., 1971). Dalam penelitian ini Madrasah Aliyah Nurul Jadid (selanjutnya disebut: MA Nurul Jadid, yang merupakan salah satu lembaga formal yang berada di bawah naungan Pondok Pesantren Nurul Jadid Paiton, Probolinggo akan dijadikan model dalam implementasi pengelolaan nirsampah mandiri (autonomous zero waste management) di Pesantren Nurul Jadid. Adapun profil pengelolaan sampah di MA Nurul Jadid selama ini adalah sebagai berikut.

Madrasah Aliyah Nurul Jadid memiliki peserta didik yang sebagian besar menetap di Pesantren Nurul Jadid. Jumlah keseluruh siswa di MA Nurul Jadid adalah sebanyak 1221 siswa. Dalam observasi awal ditemukan bahwa para siswa masih terbiasa membuang sampah dalam satu tong sampah, sehingga menyebabkan sampah organik dan anorganik tercampur di dalamnya. Pada kebanyakan kelas hanya tersedia satu tong sampah untuk menampung semua jenis sampah, baik organik maupun anorganik. Meskipun demikian, pada beberapa tempat terlihat terdapat lebih dari satu tempat sampah di depan kelas. 
Akan tetapi sampah masih tetap dalam kondisi tercampur.

Atas sampah-sampah yang ada dan juga untuk menjaga kebersihan lingkungan sekolah, MA Nurul Jadid memiliki petugas kebersiahan sebanyak lima orang yang bertugas di pagi hari sebelum sekolah dimulai. Para petugas kebersihan ini akan mengangkut sampah-sampah itu ke pinggir jalan di luar pagar sekolah dimana petugas kebersihan pesantren akan mengangkutnya dengan menggunakan truk sampah ke Tempat Pembuangan Sampah (TPS) milik pesantren yang lokasinya berada di luar lahan pesantren.

Sesampai di TPS, sampah-sampah itu ditampung, sekali lagi, tetap dalam kondisi tercampur, dipilah semampunya, dan sisanya dibakar karena jumlah sampah yang datang adalah sebesar lima ton setiap harinya maka tidak semua sampah mampu dipilah antara yang organik dan non organik oleh petugas lapangan yang jumlahnya hanya lima orang itu. Sayangnya, tidak semua sampah mampu dibakar. Pembakaran sampah hanya bisa dilakukan pada pagi hingga sore hari saja, yakni jam 09.00 hingga pukul 15.00. Ini adalah hasil kesepakatan antara pengelola sampah dengan warga sekitar TPS.

Pembakaran sebelum jam 09.00 dan selepas jam 15.00 tidak dapat dilakukan karena warga sekitar merasa keberatan dan merasa terganggu bila pembakaran sampah dilakukan pada jamjam dimana mereka dan keluarganya ada di rumah. Kondisi ini menyulitkan para petugas di TPS mengingat banyaknya tambahan timbunan sampah setiap harinya. Oleh karena itu, ratarata sampah yang mampu dibakar setiap harinya tidak lebih dari 1/6 (seperenam) nya. Dapat diperkirakan bahwa sampah-sampah itu kemudian teronggok, membusuk, serta dan mengundang segala dampak negatifnya: bau busuk, belatung, lalat, tikus, dan bahkan ular.

Penelitian ini dimaksudkan untuk mencari rancangan pengelolaan nirsampah mandiri berbasis lembaga pendidikan guna mengantisipasi tekanan dan konflik lebih lanjut. Rancangan meliputi aspek operasional, kelembagaan, regulasi, partisipasi, dan pembiayaan.

\section{Metode}

Jenis penelitian yang digunakan dalam penelitian ini adalah penelitian kualitatif. Penelitian kualitatif adalah penelitian yang dilatarbelakangi oleh alam, artinya penelitian ini berangkat dari keadaan alam (lapangan), sehingga tujuan dari penelitian ini berbeda dengan kuantitatif, karena tujuannya bukan untuk menguji teori, tetapi untuk memahami suatu fenomena yang ada. Dalam penelitian kualitatif, peneliti menggambarkan realitas yang sebenarnya disesuaikan dengan fenomena yang ada secara rinci, tuntas dan detail. Oleh karena itu, penelitian kualitatif mampu mengungkap fenomena-fenomena pada suatu objek yang ingin diteliti secara mendalam.

Desain penelitian ini menggunakan penelitian pengembangan, yakni penelitian yang bertujuan untuk menghasilkan produk berupa desain atau buku yang dapat menyelesaikan suatu masalah. Pada proses penelitian pengembangan, diperlukan tahapan validasi ahli sebelum uji-coba strategi. Penelitian pengembangan dimulai dengan identifikasi masalah pada objek penelitian. Tahap berikutnya adalah mengkaji teori tentang pengembangan strategi yang relevan dengan yang akan dikembangkan. Setelah menguasai teori terkait, draft tersebut perlu dikembangkan lagi dan direview berulangkali untuk mendapatkan hasil yang sesuai dengan apa yang diharapkan. Langkah terakhir dari serangkaian proses penelitian pengembangan adalah uji coba draft agar menjadi strategi yang dapat diterapkan pada suatu kegiatan pembelajaran.

Dalam tahap persiapan, peneliti terlebih dahulu harus menyelesaikan berbagai persyaratan administrasi yang terdiri dari meminta surat tugas dari Universitas Nurul Jadid melalui Lembaga Penerbitan, Penelitian, dan Pengabdian kepada Masyarakat (LP3M). Surat tugas kemudian diajukan permohonan ijin untuk melakukan penelitian kepada pengurus pesantren di Sekretariat Pesantren. Setelah surat ijin diperoleh, tembusan surat ijin diserahkan ke MA Nurul Jadid untuk dikoordinasikan teknis pelaksanaan penelitan.

Segera setelah diperoleh kesepakatan teknis pelaksanaan penelitian maka survei pendahuluan dilakukan. Survei dilakukan untuk memperoleh gambaran awal tentang prilaku membuang sampah pada civitas akademika MA Nurul Jadid, pola pengelolaan sampah yang dijalankan hingga observasi awal ini dilakukan, dan penelusuran pengelolaan timbulan sampah di sumber timbulan hingga ke TPS Nurul Jadid.

Selanjutnya, setelah dilakukan observasi awal ditentukan metode sampling atas timbulan sampah dari populasi timbulan sampah. Ada kelemahan dalam penentuan metode sampling dalam penelitian ini, yakni, mengingat penelitian ini dilaksanakan pada masa pandemi, maka jumlah timbulan sampah di sekolah menjadi 
Diagram alir metodologi perencanaan dapat dilihat pada Gambar 1 berikut ini.

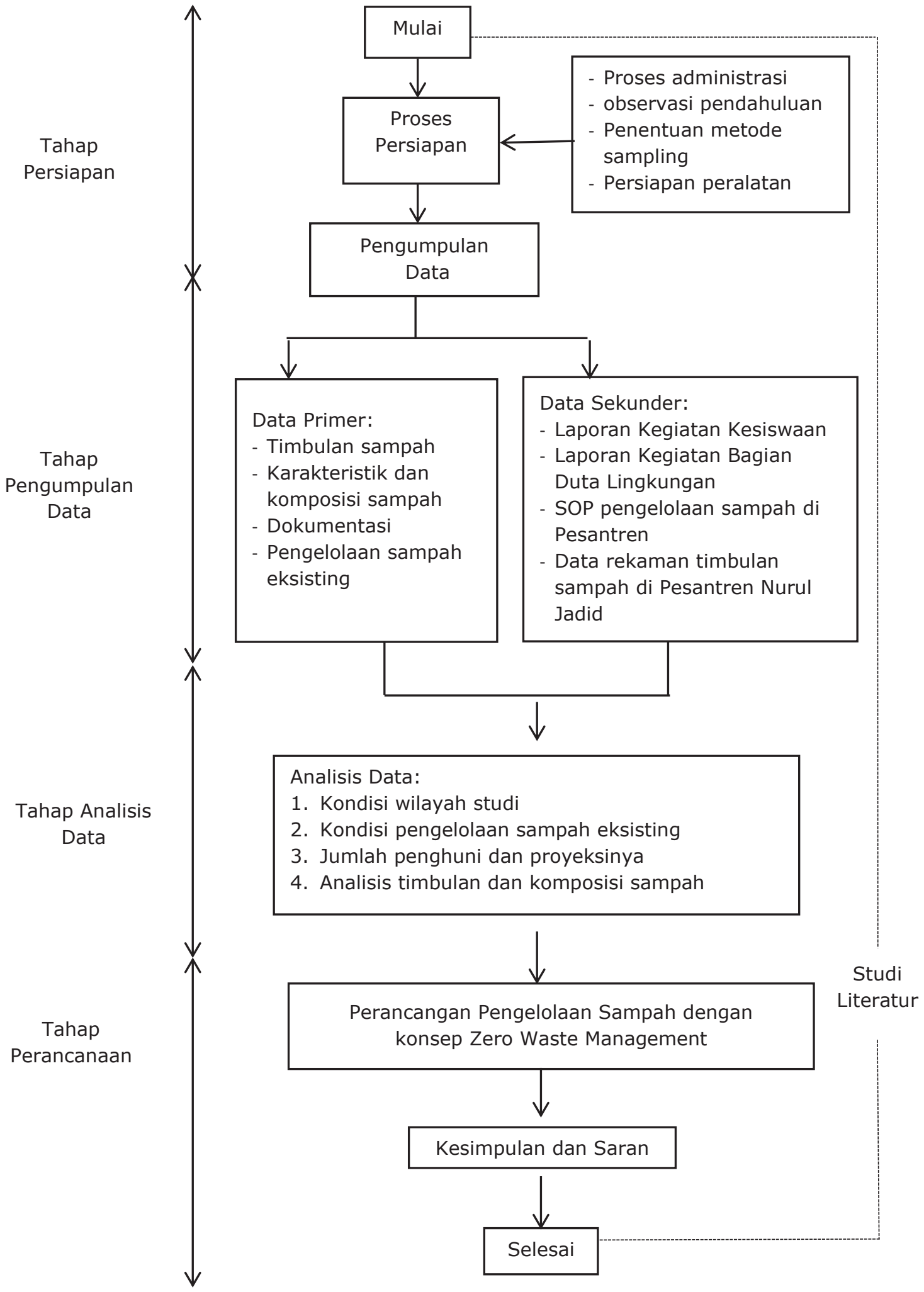

Gambar Diagram Alir Perencanaan 
data yang bukan sebenarnya. MA Nurul Jadid memberlakukan $50 \%$ jumlah total siswa yang diijinkan masuk dalam setiap harinya. Siswa diatur secara bergantian untuk masuk dalam pembelajaran tatap muka. Oleh karena itu, timbulan sampah yang ada masih $50 \%$ dari jumlah yang sebenarnya. Namun demikian, mengingat timbulan sampah ditampung pada bak-bak sampah yang ada di depan kelas, maka secara prinsip populasi dari timbulan sampah adalah apa yang ada di bak-bak sampah tersebut yang diasumsikan sebagai $50 \%$ dari keseluruhan populasi timbulan sampah.

Hal terakhir yang dilakukan dalam tahap persiapan ini adalah persiapan peralatan. Peralatan yang dibutuhkan adalah masker, sarung tangan, dan timbangan. Masker, dan sarung tangan dibutuhkan sebagai bagian dari peralatan untuk memenuhi prosedur kesehatan dan kebersihan; sementara timbagan digunakan untuk menimbang timbulan sampah pada bak-bak sampah yang dijadikan sampel.

Semua tahapan persiapan ini dilaksanakan dari tanggal 15 Januari 2021 hingga 20 Pebruari 2021. Setelah itu, penelitian memasuki tahap pengumpulan data. Data terdiri dari data primer dan data sekunder. Data primer, yakni data yang harus diperoleh langsung dari lapangan, berupa timbulan sampah, karakteristik dan komposisi sampah, dokumentasi, dan sistem pengelolaan yang dijalan MA Nurul jadid hingga penelitian ini dilakukan. Sedangkan data sekunder dalam penelitian ini adalah data yang diperoleh dari laporan kegiatan sekoleh, kesiswaan, struktur sekolah, struktur OSIM, laporan kegiatan bagian Duta Lingkungan, SOP pengelolaan sampah di Pesantren. Data rekaman timbulan sampah di Pesantren Nurul Jadid, dan lain-lain.

Atas semua data yang diperoleh kemudian dilakukan analisis data yang terdiri dari analisis kondisi wilayah studi, analisis kondisi pengelolaan sampah eksisting di MA Nurul Jadid dan Pesantren Nurul Jadid, analisis jumlah penghuni, proyeksi, dan prilaku buang sampah, dan analisis timbulan dan komposisi sampah. Hasil dari berbagai analisa ini kemudian dijadikan dasar dalam penyusunan rancangan pengelolaan sampah di MA Nurul Jadid dengan konsep Zero Waste Management - Tahapan pengumpulan data dan analisa data ini dilaksanaka dari bulan Pebruari 2021 hingga bulan Juni 2021. Akhirnya, atas rancangan yang telah disusun, pada bulan Juni 2021, dilaksanakan uji ahli oleh Kepala Bagian Pengelolaan Sampah Dinas Lingkungan Hidup Kabupaten Probolinggo.

\section{Hasil dan Pembahasan}

\section{Kondisi Existing Pengelolaan Sampah di MA Nurul Jadid}

Pembahasan kondisi existing pengelolaan sampah di MA Nurul Jadid mencakup kondisi pada aspek kelembagaan, operasional, partisipasi, regulasi, dan pembiayaan. Adapun rincian data yang diperoleh adalah sebagai berikut;

\section{Aspek Kelembagaan}

Secara kelembagaan, penanggung jawab pengelolaan sampah secara keseluruhan di Pesantren Nurul Jadid BKLH (Badan Kebersihan dan Lingkungan Hidup). BKLH Pesantren Nurul Jadid bertanggung jawab atas kebersihan di lingkungan pesantren secara keseluruhan dan petugas kebersihan (kebun) MANJ. Tugas BKLH yakni mengangkut seluruh sampah yang berada di lingkungan pesantren menuju ke TPS luar pesantren. 7539

Secara umum dapat dijelaskan bahwa jumlah keseluruhan santri putra dan santri putri yang ada di pesantren adalah sebanyak 7539 orang. Jumlah ini tersebar di berbagai lembaga pendidikan yang dimiliki, yakni Madrasah Tsanawiyah Nurul Jadid (MTs. NJ), Madrasah Aliyah Nurul Jadid (MANJ), Sekolah Menengah Pertama Nurul Jadid (SMP NJ), Sekolah Menengah Atas (SMANJ), dan Sekolah Menengah Kejuruan (SMKNJ). Jika ditambah dengan civitas akademika di Universitas Nurul Jadid yang berjumlah 5.000 orang yang juga memiliki timbulan sampah, maka beban timbulan sampah yang menjadi tanggung jawab BKLH Pesantren Nurul Jadid adalah, lebih kurang, sebesar 13 ribu orang.

Untuk mengelola timbulan sampah yang timbul pada setiap harinya, maka dibuat aturan, yakni masing-masing lembaga pendidikan harus mengangkat pengurus dan penanggung jawab kebersihan dan lingkungan hidup di lembaga masing-masing yang lazim disebut "kebun". Para petugas kebun ini diberi tanggung jawab untuk membersihkan dan menampung sampah pada bak-bak sampah yang ada, dan kemudian mengantarkan bak-bak sampah itu ke pinggir jalan yang menjadi akses jalannya truk sampah BKLH. Oleh karena itu, MA Nurul Jadid mengangkat sebanyak lima orang "kebun" untuk menjaga kebersihan dan lingkungan hidup di MA Nurul Jadid.

Selain "kebun", MA Nurul Jadid juga memiliki bagian Duta Lingkungan dalam struktur Organisasi Siswa Intra Madrasah (OSIM). Bagian Duta Lingkungan ini diberi tanggung jawab 
mengelola Mading sebagai sarana komunikasi dan informasi khusus masalah lingkungan hidup, menyelenggarakan kegiatan-kegiatan terkait lingkungan, serta berbagai pegelaran yang ditujukan untuk meningkatkan kesadaran lingkungan bagi siswa dan siswi MA Nurul Jadid. Dari keterangan yang diberikan oleh Eko Wahyudi, guru MA Nurul Jadid yang menjadi pembina OSIM, dinyatakan bahwa kegiatan-kegiatan yang terkait lingkungan hingga saat ini masih sulit dilakukan karena masih murni mengandalkan kesadaran; belum diatur secara ketat tentan reward and punishment terkait kesadaran untuk menjaga kelestarian lingkungan. Kondisi ini yang menyebabkan masih belum mampu dipilahnya sampah organik dan non organik yang pada gilirannya ikut menyumbang rumitnya permasalahan penanganan sampah di Pesantren Nurul Jadid secara keseluruhan.

Dapat disarikan bahwa dalam aspek kelembagaan, pengelolaan sampah di MA Nurul Jadid yang merupakan bagian dari Pesantren Nurul Jadid telah memiliki struktur lembaga, gambaran kerja, dan kewenangan yang jelas dalam pengelolaan timbulan sampah. Penanganan sampah dari sumber timbulan hingga ke tempat penjemputan sampah oleh para petugas pengelola sampah di tingkat pesantren dilakukan oleh para petugas "kebun". Selanjutnya oleh BKLH Pesantren Nurul Jadid sampah akan dibawa ke TPS yang juga sekaligus TPA untuk dikelola lebih lanjut. Hanya saja, kondisi timbulan sampah yang ditangani masih dalam keadaan tercampur sehingga dibawa ke TPS juga dalam kondisi tercampur dan menyulitkan pengelolaannya. Yang perlu diperbaiki adalah bagaimana memberikan edukasi, baik kepada para pengelola sampah di MA Nurul Jadid yang disebut "kebun", dan juga kepada segenap civitas akademika MA Nurul Jadid perihal pemilahan timbulan sampah, pengelolaan timbulan sampah yang ada, hingga pemanfaatan timbulan sampah yang ada.

\section{Aspek Operasional}

Pengelolaan sampah yang dilaksanakan di sekolah MANJ menggunakan sistem pewadahan, pengumpulan, dan pengangkutan. Pewadahan timbulan sampah dilakukan dengan menyediakan bak-bak sampah di depan kelas dan pada setiap pojok gedung. Pada setiap kelas disediakan satu bak sampah, dan pada setiap pojok gedung tersedia paling sedikit dua bak sampah.

Wadah yang ada di depan kelas digunakan untuk menampung bermacam jenis sampah yang dibuang oleh para murid. Dari wadah-wadah yang ada, sampah kemudian dikumpulkan oleh petugas kebersihan (kebun) saat jam pulang sekolah. Para petugas kebersihan kemudian mengumpulkan seluruh sampah ke dalam satu wadah besar langsung seperti apa adanya tanpa dilakukan pemilahan terlebih dahulu. Petugas sampah (kebun) kemudian membawa sampah tersebut ke pinggir jalan depan sekolah untuk diangkut oleh BKLH pesantren ke TPS di luar pesantren dengan truk pengangkut sampah. Di TPS, sampah tersebut dibakar oleh petugas BKLH, karena jumlahnya yang sangat banyak dan tercampur tidak memungkinkan untuk dipilah dan dikelola.

Dari sini terlihat bahwa pelaksanaan pengelolaan sampah masih menganut sistem kumpul, angkut, buang. Hal ini terjadi karena timbulan sampah masih tercampur sejak dari sumbernya. Oleh karena itu, di tahapan berikutnya menjadi sulit untuk dilakukan pemilahan dan juga pengelolaan yang ramah lingkungan. Timbulan sampah dari 2000 siswa dan siswi yang berjumlah 800 kilogram tidak mungkin bisa ditangani secara baik oleh tidak lebih dari lima orang petugas kebersihan "kebun" dan enam orang petugas BKLH. Kondisi ini akan berbeda bila timbulan sampah dapat dipilah sedari awal: sejak dari sumbernya. Petugas kebersihan "kebun" akan langsung memasukkan ke komposter untuk sampah organik, dan menempatkan di tempat penjemputan sampah untuk sampah anorganik. Lebih jauh lagi, para petugas BKLH juga akan menerima beban yang jauh lebih ringan karena hanya menangani sampah anorganik saja; tanpa sampah organiknya karena sampah organik telah tuntas dikelola secara mandiri di tingkat lembaga pendidikan.

\section{Aspek Partisipasi}

Partisipasi civitas akademika MA Nurul Jadid OSIM (Organisasi Siswa Intra Madrasah) MA Nurul Jadid dalam menjaga kebersihan lingkungan sekolah masih rendah. Bagi sebagian besar civitas akademika MANJ, urusan sampah adalah urusan "kebun". Dalam pandangan mayoritas civitas akademika, bersih atau tidaknya lingkungan sekolah bukan urusan mereka. Masalah kebersihan sekolah adalah urusan "kebun".

Hanya saja, ada hal yang menggembirakan bahwa di OSIM ada bagian yang diberi tanggung jawab untuk menjaga lingkungan, yakni seksi Duta Lingkungan. Seksi Duta Lingkungan memiliki program kerja khusus bagi para murid untuk menumbuhkan kesadaran menjaga kebersihan 
lingkungan. Beberapa program yang dijalankan Duta Lingkungan adalah mengadakan piket untuk menjaga kebersihan Aula Mini bagi kelas $X$ dan XI, melakukan pengontrolan sepatu, menempel slogan keindahan dan kebersihan di tempat tertentu, melaksanakan kegiatan diet sampah untuk mengurangi sampah anorganik, melaksanakan kegiatan bersih-bersih madrasah bagi seluruh siswa dan siswi setiap dua bulan sekali. Selain seksi Duta Lingkungan, bagian sarana pra sarana sekolah juga memfasilitasi alat kebersihan sekolah.

Dari uraian diatas terlihat bahwa partisipasi civitas akademika MANJ perlu ditingkatkan, yakni pelibatan sejak dari perencanaan, pelaksanaan, dan juga evaluasi kondisi lingkungan dan pelaksanaan program. Bila hal ini mampu dilaksanakan maka kondisi lingkungan sekolah akan terjaga dan langkah untuk mewujudkan visi sekolah juga akan lebih mudah dilakukan.

\section{Aspek Regulasi}

Regulasi terkait upaya menjaga kebersihan lingkungan sekolah dan pengelolaan sampah dibuat oleh seksi Duta Lingkungan untuk siswa dan siswi. Diatur misalnya, bahwa siswa dan siswi yang melanggar program kerja seksi Duta Lingkungan, seperti tidak melaksanakan piket membersihkan Aula Mini, maka yang bersangkutan wajib menyapu halaman sekolah saat istirahat pertama. Bila ditemukan di sebuah kelas ada sepatu yang berserakan dan tidak diletakkan di rak sepatu yang disediakan maka yang bersangkutan dikenakan sanksi membersihkan daerah tertentu dan membaca istighfar 33 kali. Contoh lain dari regulasi ini adalah bila terdapat kelas kotor, maka diantara kelas-kelas yang kotor itu, yang terkotor dikenakan sanksi untuk membersihkan kamar mandi dan mengganti kresek kamar mandi.

Terlihat disini bahwa regulasi yang dibuat belum memiliki kekuatan untuk dijalankan karena dibuat oleh Duta Lingkungan, dikawal oleh seksi Duta Lingkungan dimana personilnya adalah para siswa. Selain tidak memiliki kekuatan, regulasi yang dibuat juga tidak dapat menggerakkan para guru. Akibatnya, saat ada sampah berserakan di depan kelas atau di pojok-pojok gedung, terlihat para guru abai dan tidak memedulikan kondisi berserakannya sampah-sampah tersebut. Kondisi ini akan berbeda bila regulasi diatur oleh kepala sekolah secara langsung. Seluruh civitas akademika akan mudah digerakkan dan regulasi akan menyasar seluruh civitas akademika tanpa terkecuali.

\section{Aspek Pembiayaan}

Dari sisi pengeluaran, biaya yang dikeluarkan masih sebatas pembelian alat kebersihan, dan biaya penyelenggaraan program oleh seksi Duta Lingkungan. Belum ada rencana untuk pembangunan instalasi pengelolaan sampah secara mandiri di sekolah. Adapun alokasi anggaran diambilkan dari pos anggaran di sekolah. Dari wawancara yang dilakukan, hingga saat ini tidak ada iuran dari siswa/siswi untuk pengelolaan sampah di MANJ.

\section{Desain yang Diusulkan Aspek Kelembagaan}

Pada aspek kelembagaan, penanggung jawab pengelolaan sampah pada skala pesantren diusulkan untuk tetap ditangani oleh BKLH dan di skala madrasah ditangani oleh sekolah dalam hal ini kepala sekolah melalui wakil kepala sekolah bagian sarana prasarana atau wakil kepala sekolah bagian kesiswaan. Dengan demikian maka kebijakan sekolah untuk melakukan pengelolaan nirsampah pada tingkat sekolah akan menyasar seluruh civitas akademika. Dengan penataan kelembagaan seperti ini maka aspek-aspek yang lain juga akan langsung memperolah dukungan secara langsung dari sekolah.

Dengan demikian, Duta Lingkungan dan petugas kebersihan (kebun) akan bertanggung jawab secara teknis di lapangan saja. Tugas seksi Duta Lingkungan di OSIM dan "kebun" akan menjadi lebih ringan, yakni menjamin pelaksanaan visi pengelolaan nirsampah di tingkat sekolah.

Secara operasional di lapangan, struktur organisasi seksi Duta Lingkungan dengan dibantu "kebun" sudah cukup memadai untuk menyelenggarakan kegiatan kumpul, angkut, buang. Dengan dibantu koordinator untuk wilayah putra dan putri, penanganan sampah sudah bisa menjangkau hingga para ketua kelas yang merupakan produsen atau sumber timbulan sampah. Para ketua kelas yang bertanggung jawab atas pelaksanaan pewadahan dan pemilahan sampah di kelas masing-masing, telah mampu menjaga kebersihan lingkungan sekolah pada tingkat terbatas kelas masing-masing.

Masalah sampah terlihat muncul pada pojokpojok sekolah dimana ditempatkan dua hingga tiga bak sampah disana. Pojok sekolah merupakan wilayah open access area dimana tidak ada yang merasa bertanggung jawab; namun semua civitas akademika merasa berhak untuk berbuat semaunya disana. Situasi ini menjadikan permasalahan sampah menjadi pelik karena sampah berserakan pada setiap pojok sekolah. 
Memang masalah ini dapat teratasi keesokan harinya saat petugas kebersihan "kebun" melaksanakan tugasnya dimana sampah-sampah itu diangkut ke gerobak untuk dibawa ke tempattempat penjemputan sampah dari setiap lembaga pendidikan oleh BKLH.

Untuk itu, dalam rancangan ini diusulkan agar struktur organisasi pengelolaan sampah ini tidak lagi dibebankan semata-mata kepada seksi Duta Lingkungan dan "kebun" saja karena ini akan membatasi ruang gerak, dan kewenangan mengingat kemampuan dan kapasitas yang terbatas. Akan tetapi bila para pengurus Duta Lingkungan dan "kebun" ini diberikan tugas untuk mengelola sampah yang sudah terpilah, kemudian membawa sampah organik ke lahan atau tong komposter, serta membawa sampak anorganik ke tempat penjemputan sampah oleh BKLH, maka pengurus Duta Lingkungan dan "kebun" sudah terbukti cakap untuk itu.

. Dapat disimpulkan bahwa pembagian tugas antara BKLH dengan petugas pengelola sampah di tingkat sekolah sudah baik. BKLH bertugas mengangkut seluruh sampah yang berada di lingkungan pesantren menuju ke TPS luar pesantren; sedangkan pengelolaan sampah di skala lingkungan sekolah MA Nurul Jadid dari mulai sumber sampah sampai TPS dilaksanakan oleh Seksi Duta Lingkungan OSIM dengan bantuan petugas kebersihan (kebun) yang dibentuk/ ditunjuk oleh Kepala Madrasah. Agar dapat menjamin keberlangsungan program dan dapat menjangkau seluruh civitas akademika, kendalai utama pengelolaan sampah harus diambil alih oleh kepala sekolah.

Sebagai catatan akhir, meskipun tercatat masih sedikit, namun di MANJ juga ditemukan timbulan sampah B3 seperti baterai, sampah khusus seperti pampers dan pembalut, dan juga guguran daun. Untuk itu perlu ditangani secara khusus. Untuk sampah B3, pampers, dan pembalut wanita perlu diatur tersendiri karena perlu penanganan khusus; dan guguran daun dari pohon juga akan diatur tersendiri (tidak dimasukkan dalam tong komposter karena akan menyebabkan cepat penuhnya tong komposter).

\section{Aspek Operasional Pengelolaan Nirsampah Mandiri}

Mengingat hingga saat ini belum dilakukan pemilahan, maka diusulkan agar MANJ segera menerapkan sistem penanganan sampah dengan memilah sampah organik dan non organik; menerapkan teknik 3R di sumber dan TPS; menangani sampah khusus dengan berkoordinasi dengan BKLH.

Secara berurutan, langkah yang perlu dilakukan adalah sebagai berikut. Kepala Madrasah, melalui Bagian Sarana Prasarana harus menyediakan minimal 2 buah wadah sampah untuk setiap kelas, dengan ketentuan bahwa wadah sampah organik untuk mewadahi sampah sisa sisa makanan, kulit buah-buahan, dan daundaunan menggunakan wadah dengan warna gelap; sedangkan wadah sampah anorganik untuk mewadahi sampah jenis plastik, dan lain-lain menggunakan wadah dengan warna terang. Dua wadah tersebut kemudian ditempatkan di depan kelas masing-masing. Di bawah tanggung jawab ketua kelas, siswa dan siswi yang memiliki piket kelas wajib memilah sampah.

Dengan metode pengumpulan sampah yang dilakukan pada skala kelas maka siswa/siswi secara individual sebagai anggota kelas memilah sendiri sampahnya ke wadah komunal yang sudah ditentukan). Setepas jam sekolah, petugas kebersihan (kebun) mengumpulkan sampah organik untuk dimasukkan ke dalam tong atau lahan komposter setiap hari dan mengumpulkan sampah anorganik untuk diangkut ke instalasi pengolahan sampah anorganik. Di instalasi pengolahan sampah anorganik petugas kebersihan (kebun) mencuci, mengeringkan, dan memilah sampah anorganik, menjual sampah bernilai ekonomis dan dapat mengolah menjadi ecobrick untuk sampah anorganik yang tidak bernilai ekonomis. Pembuatan ecobrick ini perlu dikoordinasikan dengan waka kurikulum untuk disinergikan dengan mata pelajaran prakarya (muatan lokal).

Untuk sampah-sampah yang tidak bisa diolah di MANJ, seperti seperti pampers, pembalut, dan building demolition, petugas kebersihan (kebun) mengangkut sampah-sampah jenis ini ke pinggir jalan depan sekolah untuk selanjutnya diangkut oleh petugas BKLH ke TPS di luar area pesantren dengan menggunakan truk pengangkut sampah.

\section{Aspek Partisipasi}

Sebagaimana dijelaskan sebelumnya bahwa partisipasi dari civitas akademika MANJ sangat rendah dalam pengelolaan sampah. Rendahnya partisipasi itu terlihat dari berserakannya sampah-sampah yang ada di pojok setiap ruangan. Salah seorang siswi yang diwawancarai menyatakan bahwa tanggung jawab kebersihan sekolah adalah tanggung jawab "kebun" yang akan membersihkan lingkungan sekolah pada 
pagi hari sebelum jam 07.00. Dinyatakan juga bahwa tanggung jawab siswa adalah menjaga kebersihan kelas. Disini terlihat bahwa, dalam pandangan siswa, tanggung jawab kebersihan adalah tanggung jawab "kebun" saja.

Pernyataan siswa ini serupa dengan pernyataan dari salah satu guru di MANJ. Saat diwawancarai, guru tersebut menyatakan bahwa siswa memang tidak dibebani tanggung jawab untuk menjaga kebersihan sekolah. "Mereka hanya dihimbau saja supaya jangan buang sampah sembarangan, meletakkan sepatu dengan tertib di rak sepatu yang disediakan, dan menjaga kebersihan kelas".

Dari dua wawancara ini terlihat bahwa partisipasi civitas akademika MANJ perlu untuk ditingkatkan. Untuk meningkatkan peran guru, siswa, dan siswi dalam pengelolaan nirsampah mandiri, perlu dilakukan edukasi, pelibatan guru dan siswa dalam setiap tahapan proses pengambilan keputusan, dan juga regulasi agar siswa/siswi, guru, dan seluruh tenaga kependidikan melakukan pemilahan sampah di sumber. Selanjutnya, siswa/ siswi, guru, dan seluruh tenaga kependidikan diberikan pemahaman tentang pengolahan sampah dengan konsep 3R. Seluruh aturan ini perlu dituangkan dalam peraturan yang ditetapkan oleh kepala madrasah. Terakhir, seluruh siswa/siswi, guru, dan seluruh tenaga kependidikan berperan aktif dalam sosialisasi dan edukasi pengelolaan nirsampah.

\section{Aspek Regulasi}

Aspek-aspek yang telah dibahas sebelumnya perlu dikawal dalam peraturan resmi guna menjamin kejelasan aturan main dan keberlanjutan program. tertulis terkait pewadahan, jadwal pengumpulan, dan pengaturan sanksi terhadap pelanggaran di lingkungan sekolah. Hal-hal yang perlu dijadikan prioritas pengaturan adalah sebagai berikut.

Pertama adalah pengaturan pewadahan sampah dan pemilahan sampah sejak dari sumbernya. Pewadahan sampah minimal harus dalam dua wadah, yaitu organik (warna gelap) dan anorganik (warna terang). Kedua wadah ini ditempatkan di depan setiap kelas. Dengan demikian maka sudah memenuhi asas kelayakan untuk meminta siswa dan siswi suapaya memilah sampah organik dan anorganik pada tempat sampah masing-masing.

Selanjutnya, di tempat pengolahan, untuk setiap kelas wajib disediakan minimal 3 (tiga) buah tong komposter ukuran 60 liter untuk mengompos sampah organik. Ini untuk menampung timbulan sampah-sampah organik dari setiap kelas yang setiap harinya adalah sebanyak:

$$
(0,6 \% \times 0.4 \mathrm{~kg}) \times 30=7,2 \mathrm{~kg} \text {. }
$$

Jika konversi $1 \mathrm{~kg}$ adalah 0.753 liter, maka $7,2 \mathrm{~kg}$ adalah sama dengan:

$7,2 \mathrm{~kg} \times 0,753=5,414$ liter perhari/kelas.

Dengan demikian dalam satu bulan kebutuhan wadah penampungan untuk timbulan sampah organik adalah sebanyak:

\section{5,414 liter $\times 26$ hari $=140,76$ liter/bulan .}

Jumlah 140 liter timbulan sampah organik ini membutuhkan 3 (tiga) buah tong komposter. Hal ini bila diasumsikan sebagai benda padat. Akan tetapi mengingat sampah organik ini juga menghasilkan lindi setelah 24 jam, maka dua tong komposter dengan kapasitas 60 liter, yakni total 120 liter akan mencukupi karena jumlah lindi yang dihasilkan pada setiap kilogram timbulan sampah organik adalah sebesar 0,775 liter/kg sampai dengan 1,417 liter/kilogram (Purwanta dan Susanto, 2017). Dengan demikian, bila perhari dihasilkan 7,2 kg atau setara dengan 5,414 liter maka lindi yang dihasilkan sampai dengan tidak keluar lagi adalah sebesar:

\section{0,775 liter $\times 7,2 \mathrm{~kg}=5,5$ liter.}

Jadi, untuk timbulan sampah organik sebenarnya setelah diproses dalam komposter sebenarnya tidak membutuhkan ruang yang terlalu banyak karena hampir seluruhnya akan menjadi lindi.

Pengaturan lebih lanjut yang harus diperhatikan adalah pengontrolan ketertiban pewadahan sampah. ketertiban pewadahan samph perlu dikontrol pada setiap jam pulang sekolah, yakni mengecek apakah masig-masing kelas telah memilah sampah dengan benar atau tidak. Di bawah arahan kepala madrasah dan wakil kepala madrasah, seksi Duta Lingkungan dapat diberdayakan untuk membuat laporan setiap harinya perihal pelaksanaan ketertiban pewadahan timbulan sampah ini.

Selanjutnya adalah pengumpulan sampah. sampah-sampah yang terpilah ini dikumpulkan dan dikelola setiap hari. Sampah organik akan dibawa ke tong-tong komposter, sampahsampah anorganik yang laku dijual dipilah dan dijual sebagai tambahan pendapatan untuk para petugas kebersihan (kebun). Untuk sampah B3 
dan sampah khusus lainnya dikumpulkan dan diolah di tempat yang disediakan oleh BKLH. Dengan pengaturan seperti ini maka lahan yang seluas $3000 \mathrm{~m}^{2}$ akan lebih terbebas dari tekanan timbulan sampah.

\section{Aspek Pembiayaan}

Sumber biaya pengelolaan nirsampah mandiri di tingkat sekolah adalah berasal dari APBM (Anggaran Pendapatan dan Belanja Madrasah). Jenis pembiayaan yang dibutuhkan meliputi biaya pembelian tong komposter, biaya pembelian wadah sampah untuk ditempatkan di depan kelas, biaya petugas sampah (kebun). Selain tiga item pembiayaan ini ada biaya investasi terdiri dari alat pengomposan, kendaraan pengumpul sampah (gerobak), dan instalasi pengolahan (bangunan, peralatan daur ulang, dan lainnya).

\section{Kesimpulan}

Dari uraian di bab I hingga bab IV dapat disimpulkan bahwa dari aspek kelembagaan, operasional, partisipasi, regulasi, dan pembiayaan di MANJ masih berada dalam paradigma kumpul, angkut, buang. Semua jenis timbulan sampah masih "sekedar" dikumpulkan secara tercampur, kemudian diangkut, dan dibuang di TPS yang disediakan oleh Pesantren Nurul Jadid. Dengan jumlah total penghuni pesantren, civitas akademika lembaga pendidikan dasar dan menengah, dan civitas akademika Universitas Nurul Jadid yang berjumlah 12.000 orang, maka TPS yang disediakan pesantren yang seluas $3.000 \mathrm{~m}^{2}$ saat ini sudah tidak mampu menampung timbulan sampah dari 12.000 orang ini.

Untuk itu, penelitian ini menyusun usulan desain pengelolaan nirsampah mandiri di tingkat lembaga pendidikan. Desain yang disusun meliputi aspek meliputi kelembagaan, operasional, partisipasi, regulasi, dan pembiayaan. Ia disusun dalam paradigma pengelolaan nirsampah mandiri di tingkat lembaga pendidikan. Dalam rancangan ini diharapkan sekolah menjadi nirsampah melalui pengelolaan timbulan sampah yang dijadikan kompos, ecobrick, dan dijual atau dikelola dalam model bank sampah.

\section{Daftar Pustaka}

Anonim. (2008). UU no 18/2008 tentang pengelolaan sampah. In Jakarta.

Anonim. (2020). Media Indonesia. In Media Indonesia Rabu 17 Juni 2020,. https:// mediaindonesia.com/humaniora/321097/ timbulan-sampah-capai-678-juta-ton

Badan Standardisasi Nasional. (2008). SNI 3242:2008 tentang Pengelolaan sampah di permukiman. Badan Standardisasi Nasional, 1-23.

Badan Standarisasi Nasional. (2002). Tata Cara Teknik Operasional Pengelolaan Sampah Perkotaan. ACM SIGGRAPH 2010 Papers on - SIGGRAPH '10, ICS $27.180,1$. http://portal.acm.org/citation. $\mathrm{cfm}$ ?doid $=1833349.1778770$

Brotosusilo, A., Nabila, S. H., Negoro, H. A., \& Utari, D. (2020). The level of individual participation of community in implementing effective solid waste management policies. Global Journal of Environmental Science and Management, 6(3), 341-354. https:// doi.org/10.22034/gjesm.2020.03.05

Departemen PU. (2007). Pedoman Umum 3R Permukiman.

Kasam, Iresha, F. M., \& Setyoadi, N. H. (2019). Management of Municipal Solid Waste in Religious Tourism Park Based on Reduce, Reuse and Recovery: An Indonesian Attraction Case Study. MATEC Web of Conferences, 280, 05017. https://doi. org/10.1051/matecconf/201928005017

Pujiati, A. (2019). Gaya Hidup Minim Sampah Dan Ecobrick Alternatif Solusi. November, 890-895. https://doi.org/10.30998/ simponi.v0i0.468

Purwanta, Wahyu dan Susanto, J.P. 2017. Laju Produksi dan Karakterisasi Polutan Organik Lindi dari TPA Kaliwlingi, Kabupaten Brebes. Jurnal Teknologi Lingkungan. Volume 18 No. 2. Juli 2017. 157-164.

Rogers, E.M., Shoemakter, F. . (1971). Communication of Innovation (Second Edi). The Free Press A Division of MacMillian Publishing Co. Inc. Collier MacMillian Publisher.

Sari, S. K., Syarifudin, \& Sudarno. (2012). Masterplan Pengelolaan Sampah Mandiri di Kawasan Bukit Semarang Baru. Universitas Diponegoro.

Zaharani, Y., Putri, M. T. G., \& Nurcahyawati, E. (2020). Pelatihan Pembuatan Pot Lukis Sebagai Media Sosialisasi Kurangi Plastik di Sekolah Paket UPT Pasar Sukatani Depok. Jurnal PkM Pengabdian Kepada Masyarakat, 3(2), 245. https://doi.org/10.30998/ jurnalpkm.v3i2.4728 